\title{
Economic Shocks and the Growth of the Construction Industry in Ghana Over the 50-Year Period From 1968 to 2017
}

\author{
Kwabena Asomanin Anaman ${ }^{1} \&$ Irene Susana Egyir ${ }^{1}$ \\ ${ }^{1}$ Department of Agricultural Economics and Agribusiness, College of Basic and Applied Sciences, University of \\ Ghana, Legon, Accra, Ghana \\ Correspondence: Kwabena Asomanin Anaman, Professor, Department of Agricultural Economics and Agribusiness, \\ College of Basic and Applied Sciences, University of Ghana, Legon, Accra, Ghana.
}

Received: May 8, 2019

doi:10.5430/rwe.v10n1p1
Accepted: June 2, 2019

Online Published: June 9, 2019

URL: https://doi.org/10.5430/rwe.v10n1p1

\begin{abstract}
The study analyses the relationship between the growth of the construction industry and economic shocks in Ghana over the 50-year period from 1968 to 2017 using an autoregressive modelling scheme that incorporates several economic shocks as separate independent variables. The independent variables used in the model included one positive economic shock and five negative shock variables. The positive shock variable was the sharply increased government expenditures on construction activities in selected years that allowed the government to host international events in Ghana within a period of two years. The five adverse economic shocks included in the model were political instability related to military coups, exchange rate depreciation of the local currency, Ghana cedi, with respect to the United States dollar, the average yearly temperature, aggregate electricity energy production shortfall related to a severe El Nino weather phenomenon, and incidence of extreme rainfall. The results of the analysis indicated that the most important factor influencing the growth of the construction industry in Ghana over the 50 -year study period was political instability. Beyond political instability, the next most important factor was the purposely-driven sharp increases in government expenditures on construction activities for selected years that allowed the country to host international events in the country. The other significant economic shocks were the exchange rate depreciation, average temperatures, and electricity energy production shortfall; all three factors adversely affected the growth of the construction industry. The results of our study are generally consistent with those obtained from the literature concerning the positive and negative effects of economic shocks on the construction industry.
\end{abstract}

Keywords: climate change impact, construction economics, construction industry, economic growth, economic shocks, Ghana, political economy of the construction industry

\section{Introduction and Country Overview}

Ghana is a unitary nation state in West Africa, with a current population of about 30 million, and consisting of 16 politically-administrative regions and 260 districts. The country has 89 formally-recognized social/ethnic groups, made up of nine relatively big and dominant groups, and 80 other smaller groups, based on information from various national censuses (Anaman and Bukari, 2019; Ghana Statistical Service, 2013) (Note 1). These 89 social/ethnic groups together have about 190 traditional councils (traditional states) which have continuously overseen various traditional community and cultural activities in their areas since they emerged between 300 to 600 years ago in the Gold Coast area of West Africa.

Formerly called the Gold Coast, Ghana first emerged as a contiguous geographical state entity on 6 March 1844 when 17 traditional African states in the Gold Coast area of West Africa signed a security treaty with the Government of the United Kingdom of Great Britain (Ellis, 1894; Ward, 1948, Buah, 1998). This agreement was intended to protect these 17 traditional African states from invasion by other African traditional states and other non-British European national powers trading in the Gold Coast area of West Africa. (Note 2)

Agitation for political independence by the original 17 member states of the March 1844 Treaty from the British Government started as early as March 1865 by King Aggrey of Cape Coast, just about one month after his coronation in February 1865. King Aggrey, in several letters to the British Government in London, starting from March 1865, complained about the domineering activities of the resident British Ambassador in Cape Coast in 
violation of the 1844 Treaty of Friendship. He argued for the case of genuine self government for the 17 traditional states which had signed the 1844 agreement as a security agreement of equal sovereign states. This agitation was due to the fact that the British Government had not fulfilled its obligations under the Treaty (Lynch, 1968; Nti, 2002). From the early 1850s, the British Government had moved to become more of a colonial power of the 17 traditional states rather than the leading power of an inter-state security agreement similar to the current North Atlantic Treaty Organization structure, where the United States is the leading military and economic power, but is not a colonial power. The British Government formally declared the Gold Coast entity a colony in 1874 at the beginning of the Scramble for Africa era by European nation-state powers (Ellis, 1894; Davidson, 1972; Buah, 1998).

After 92 years of various forms of agitation for political independence from Great Britain, since the start of the first independence movement in March 1865 by King Aggrey of Cape Coast, the country gained political independence on 6 March 1957, after 113 years of British rule. The last and the most important leg of the independence struggle was led by Dr. Kwame Nkrumah and the Convention People's Party (CPP) from June 1949 to March 1957. The CPP won three consecutive national elections in 1951, 1954 and 1956 to formally lead the Gold Coast to an independent country, renamed Ghana in 1957. Ghana became a Republic on 1 July 1960 (Davidson, 1972; Buah, 1998). (Note 3)

Ghana experienced its first of five successful military coups on 24 February 1966, almost nine years after political independence. The causes of this coup were related to various economic shocks (Anaman, 2006; Anaman and Bukari, 2019). These economic shocks included the temporary balance of payments crisis in 1965 resulting from historically-low world market prices for cocoa, the country's leading commodity export (refer to Kotey et al, 1974 for world cocoa prices from 1913 to 1970), and other externally-induced political economy shocks (refer to Anaman and Bukari, 2019 for more details). A 27-year period of political instability followed after the first coup on 24 February 1966 until 7 January 1993 when the Fourth Republican Constitution was promulgated.

\section{Problem Statement}

Economic shocks have been recurring in Ghana since political independence in 1957 and these shocks often affect all sectors of the economy and general society. An important economic shock in Ghana has been political instability caused by five successful and numerous attempted military coups over the period from 1966 to 1992 . This phenomenon has waned over the last three decades. Other economic shocks include international trade shocks such as sharp increases in world oil prices from 1974 to 1980 resulting from the October 1973 Arab-Israeli conflict, and the remarkable 1962-65 world cocoa price slump partly related to the oversupply of cocoa when world cocoa prices reached their lowest ever levels (refer to the International Cocoa Organization for world cocoa prices from 1957 to 2019).

A persistent economic shock observed during the Fourth Republican era, from 1993 to 2019, is the large-scale depreciation of the country's currency, the Ghana cedi, for extended periods of time, before some stabilisation of the currency is achieved often through massive interventions by the Bank of Ghana (Central Bank of Ghana). This occurred most recently during the January to March 2019 period, when the local currency, the Ghana cedi was one of the worst performing currencies in the world over that period, linked to the very poor performance of stocks in Ghana (Dzawu, 2019). High depreciation of the Ghana cedi leads to much more expensive imported inputs that affect the output of the construction industry given the dependence of the industry on imported non-labour inputs.

Another important economic shock that has affected the economy of Ghana especially over the last decade is the sharp reduction of foreign grants from Western development partners. Anaman and Bukari (2019) reported that the excessive election-year government spending in 2008 and 2012, both election years, led to sharp reduction of grants from Western development partners in 2013 and 2014 as compared to the levels of foreign grants received by Ghana from these partners over the 2004 to 2012 period. These grants from Western development partners are often important for infrastructure and construction works.

Weather-related shocks also affect the economy. These include the dramatic changes in weather and climate variability related to the El Nino weather phenomenon observed in 1962/63, 1977/78, 1982/83, 2003, 2006/2007 and 2014/2015 (Ofori-Sarpong and Annor, 2012; Economist Magazine, 2015; Anaman et al., 2017). Further, there have also been increasing average temperatures and decreasing rainfall possibly due to climate change. Considering climate variability, based on data from the World Bank (2018), from 1968 to 2015, the growth rate of annual rainfall and average annual temperature in Ghana was $1.11 \%$ and $0.08 \%$ respectively. However, over the period, from 2009 to 2015 , the growth of annual average rainfall was $-3.33 \%$ while the growth of annual average temperature was $0.33 \%$.

Specific adverse factors affecting the Ghanaian construction industry include inadequate credit programmes, and complicated procedures for securing bank loans for housing assets by lower and middle-income earners. Reduced remittances from overseas sources have been suggested by various research workers as among factors affecting the 
Ghanaian construction industry (Laryea, 2010, Karley, 2011). The direct relationship between remittances and the housing industry was suggested by Karley (2011). Karley (2011) argued that because of the nature of the economic integration of Ghana into the global system partly through migration, the global malaise resulting from the 2008 world economic slowdown affected the employment and income levels of Diaspora Ghanaians, which then led to reduced growth levels of remittances into Ghana that affected the output of the construction industry.

Anaman and Osei-Amponsah (2007) showed that the economic growth in Ghana, as measured by the annual changes in the gross domestic product (GDP), was driven by the growth of the construction industry with a three-year lag. The effect of the construction industry on economic growth in Ghana is based on the key role of the industry in accounting for well over half of the total investment expenditures (Ghana Statistical Service, 2018a). The growth of the construction industry over the last decade has been erratic. For example, the construction industry grew at an annual rate of $3.7 \%$ over the five-year period from 2013 to 2017 . This rate was low compared to the $17.9 \%$ annual growth achieved over the period, 2007 to 2012 (Ghana Statistical Service, 2018b).

As observed over the last few years, from 2013 to 2017, economic shocks affecting the construction industry retarded the growth of the overall economy, especially with the construction industry being the largest of the 21 subsectors in the economy. While the overall economic growth rate of Ghana improved in 2017 and 2018 , it was due to the large increases in the output of the oil and gas industry in those two years based on projects undertaken by the previous government over the 2011-2016 period. This improvement in the growth rate of the oil and gas industry was due to large scale government investments in that industry over the period, 2011-2016. The growth of the much bigger non-oil component (95\% of the economy) had been noticeably flat over the last six years since 2013 . This non-oil component of the economy is particularly linked to the construction industry through a range of inter-industry backward and forward linkages; its growth depends on the performance of the construction industry.

It is therefore important to establish the causal shock factors affecting the construction industry, the extent of their impacts, and also to suggest possible remedial actions in order to achieve improved growth of the of the construction industry and the entire economy. The main objective of this paper is to ascertain the influence of economic shocks on growth of the construction industry in Ghana over the 50-year period from 1968 to 2017 for which accurate data are available in the post-independence era. This paper contributes to the international economic development literature on the role and impacts of construction industry by establishing the effects of economic shocks on an industry that is a major driver of the overall economy. As such its findings are relevant for countries for which one or a few industries drive their economies.

For example, our study on economic shocks to the construction industry in Ghana could be useful for policy guidance in countries which have manufacturing industry as the key driver of their economies such as the export-driven countries of East Asia, and also for countries where oil exports are the principal drivers of their economies such as Nigeria, Venezuela and Russia. The rest of this paper is organised as follows: the next section deals with the review of the literature with some emphasis on the appropriate definitions of economic shocks and empirical works in the area. This section is followed by a description of the methodology used for the study, the results, conclusions, cited references and the endnotes.

\section{Literature Review}

\subsection{Introduction to Economic Shocks}

In the economics literature, an economic shock is defined as an unexpected or unpredictable event which has an impact on the entire economy or parts of the economy such as specific industries like the construction industry (McConnell et al., 2016). These impacts or effects of shocks can be either positive or negative (adverse). Shocks are generally regarded in economic analysis as exogenous or external to the economic system being studied. It is well established that shocks affect the economy or its component industries, such as the construction industry, through changes in both the aggregate supply curve and aggregate demand curves due to their disruptive effects.

The aggregate supply curve is affected by economic shocks when the economy is unable to produce certain levels of outputs due to the disruptions in the supply of inputs such as labour, raw materials arising from a number of factors such as strikes and sharp increases in the costs of inputs used in the production of goods and services in various industries. For example, for the construction industry, prolonged strikes by workers and related labour agitations can reduce the output of the industry. Other effects of economic shocks on aggregate supply curve of the construction industry include political instability such as military coups, natural disasters such as floods and extreme temperatures, which make construction activities impossible or difficult to be undertaken. 
Figure 1 illustrates the effect of economic shocks on aggregate supply of the economy. Without the economic shock, aggregate supply is depicted as $\mathrm{AS}_{1}$ with supply increasing proportionally with the increasing price level (P). Equilibrium level of output is achieved with $\mathrm{AS}_{1}$ equalling aggregate demand $(\mathrm{AD})$ with the equilibrium level of output being $\mathrm{Y}_{1}$. In the presence of economic shocks, the aggregate supply curve shifts to the left from $\mathrm{AS}_{1}$ to $\mathrm{AS}_{2}$ as shown in Figure 1. The equilibrium level of output now declines from $Y_{1}$ to $Y_{2}$.

Theoretically, economic shocks lead to reduction in aggregate level of output and the rise in the general level of price (inflation). An example is the flooding linked to the El Nino weather phenomenon that makes it difficult for outdoor construction activities to be undertaken continuously over a period of time. This occurred in 1962/63, and 1968 in Ghana. The year, 1968 was the wettest on record in Ghana with average rainfall amount in the country reaching 142.53 centimetres compared to the average of 96.62 centimetres of annual rainfall over the period, 1967 to 2015 (data sourced from World Bank Group (2018)).

Economic shocks affect the aggregate demand of the economy through the four components of aggregate demand: consumption, investment, government and net trade (exports minus imports) (McConnell et al., 2016). Adverse aggregate demand shocks include economic recession or downturn in the economy of trading partners, and domestic financial crisis that leads to the reduction of lending and credit by banks. Another major source of reduction in aggregate demand is the declining real world prices of agricultural commodities sold by developing countries as analysed and documented by Fernandez et al. (2017) based on real annual prices from 1960 to 2015.

Specifically, for the construction industry in Ghana, economic shocks include the failure of the government to pay large amounts of arrears owed to construction firms engaged in government-sponsored projects especially during the transition period from an outgoing government to an incoming one due to the freeze of government spending and also due to abandonment of projects. Other shocks are the reduction in remittances to individuals and communities as a result of general worldwide economic slowdown which impacts on the purchase of newly-built houses.

Figure 2 illustrates the effect of an adverse shock on aggregate demand. Without the shock, aggregate demand is depicted as $\mathrm{AD}_{1}$ with aggregate demand decreasing proportionally with the increasing price level $(\mathrm{P})$ in line with the general theory of demand. In the initial period, equilibrium level of output is achieved with $\mathrm{AD}_{1}$ equalling aggregate supply (AS) with the equilibrium level of output being $\mathrm{Y}_{1}$. In the presence of the adverse shock, the aggregate demand curve shifts to the left from $\mathrm{AD}_{1}$ to $\mathrm{AD}_{2}$ as shown in Figure 2. The equilibrium level of output declines from $Y_{1}$ to $Y_{2}$. An adverse economic shock leads to a reduction in the aggregate level of output and the reduction in the general level of price (inflation).

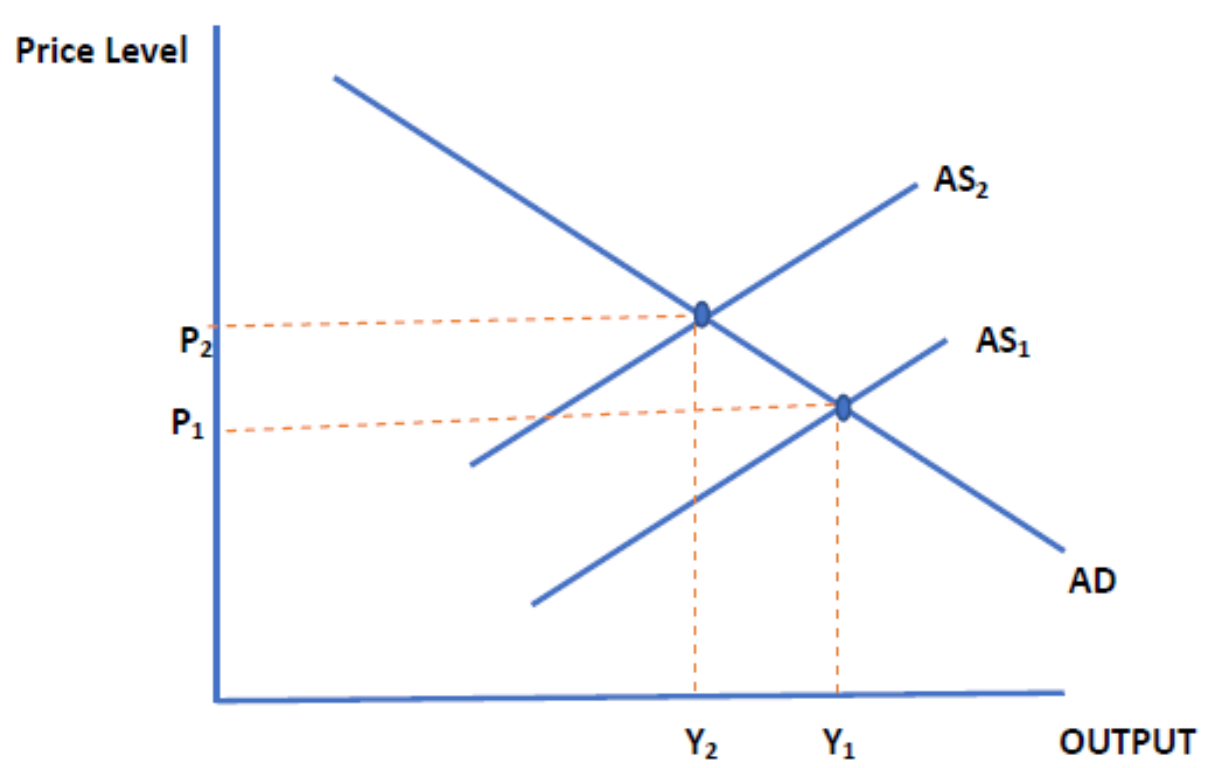

Figure 1. Illustration of the effect of an economic shock on aggregate supply of the construction industry 


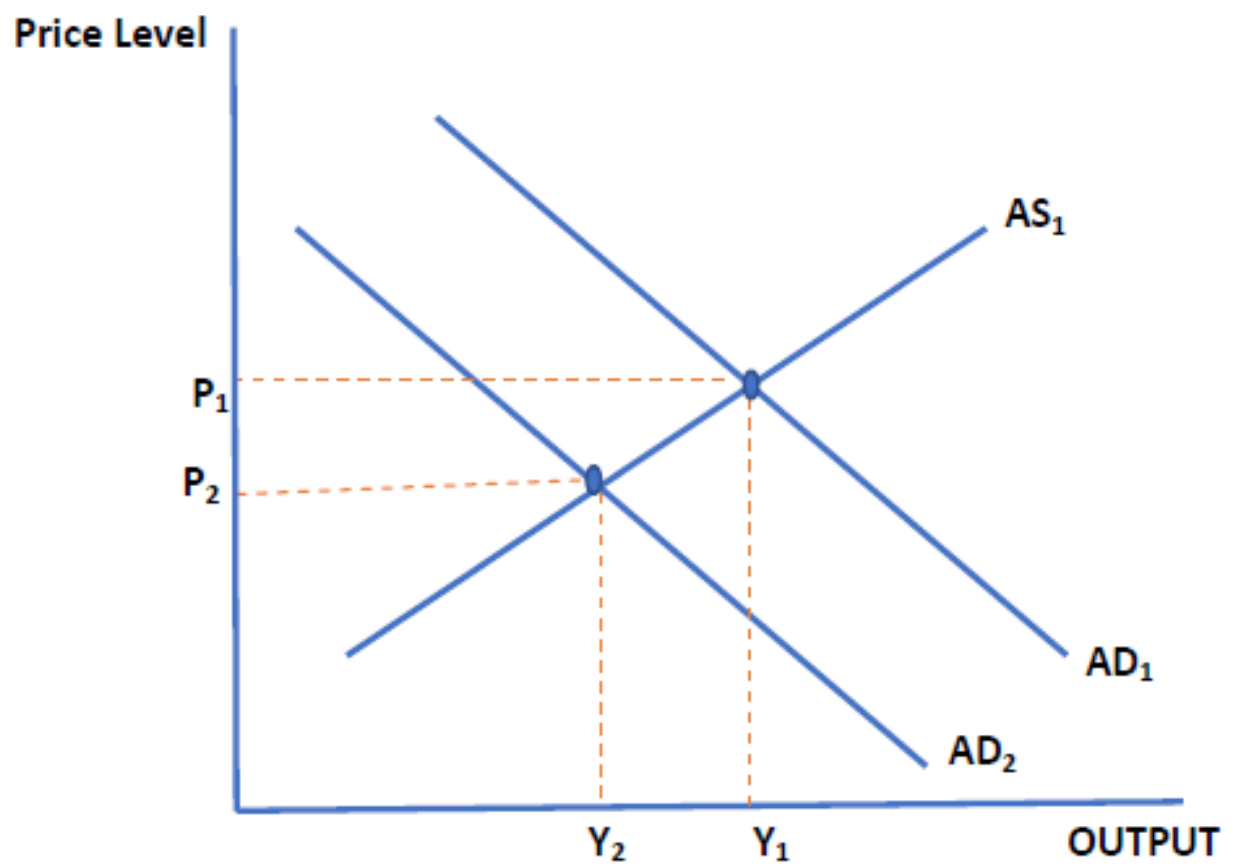

Figure 2. Illustration of the effect of an economic shock on aggregate demand of the construction industry

\subsection{Overview of Empirical Works on Economic Shocks and the Growth of the Construction Industry}

The factors that contribute to the growth of the construction industry are classified by Wang (1987, pp. 148-153) into three groups as follows: (1) external factors including macroeconomic impacts and effects, (2) organizational structure of the construction industry itself, and (3) resources such as labour and capital inputs available to individual construction firms. External factors are activities that impact the development of the construction industry and deal with the laws, regulations and rules set by the government. External factors also include social and economic conditions in the wider society including the state of the natural environment. Economic shocks are often induced from external sources which affect the capacity of the industry through the resources available to firms.

Sun et al. (2013) analysed the factors that influenced the varying shares of the construction industry as a percentage of GDP in 47 European countries over the period, 1990 to 2011. They established that the geography, demographics and economic conditions were the key determinants of the share of the GDP accounted for by the construction industry. In particular, they showed that the share of the GDP accounted for by the construction industry revolves around a simple one-lagged autoregressive scheme.

Erol and Unal (2015) analysed the relationships between the growth of the construction industry and the growth of the overall economy in Turkey based on quarterly data from 1998 to 2014. They concluded that it was the overall growth of the economy which preceded the growth of the construction industry. They suggested that the construction industry had short-lived effects on the overall economy over the 2010-2014 period due to the special treatments that favoured the industry such as radical changes in the legislations and rules concerning city building and the low-interest environment.

The linkages of the construction industry to the overall economy of Nigeria have been studied by several research workers such as Oldinrin et al. (2012) and Okoye et al. (2018) indicating the relative decline of the construction industry in recent years largely due to the relatively lower export earnings from crude oil, Nigeria's major export earner. Strong positive relationships between the outputs of the construction industry and the overall economy were shown to exist in the short-term periods.

The impact of weather events such as temperature and rainfall on the output of the construction has received growing attention linked to the relatively high interest shown for issues related to climate change, which is expected to lead to higher temperatures and reduced rainfall amounts in many countries. The inability of construction projects to meet 
deadlines and initially planned completion dates is indicated by Ballesteros-Perez et al. (2018) who cite several other works supporting their assertion. Delays in the completion of construction projects could be mitigated with access to enhanced and improved climate and weather information tied to specific geographical sites.

El-Rayes and Moselhi (2001) noted the considerable impact of heavy rainfall on highway construction works and developed a decision support system to evaluate the impact of heavy rainfall on highway construction works. Dell et al. (2014) review more recent literature involving panel data models that assess the impacts of rainfall, temperatures and windstorms on economic outcomes. Their work includes concepts related to the development of economic damage functions for possible future climate change.

Another source of economic shock, noted earlier for the Ghanaian case, but which is applicable to other countries, is the long delay in the payment of work done by construction companies for governments, both local and national. Sumardi (2003) indicated that this issue was the most important factor affecting the efficiency of construction firms in Brunei Darussalam. Political instability is known to considerably affect the performance and outputs of the construction industry. For example, Sultan and Alaghbari (2018) have indicated that the continuing civil war in the Republic of Yemen has led to drastic reduction of the construction outputs in the formal sector, and has led to a considerable shift of construction activities to the informal sector. Based on a survey, they established that the informal construction subsector accounts for over $90 \%$ of activities in the construction industry in Yemen. Political instability also affects the construction industry through a variety of other forms. Military coups, including even unsuccessful coups, create an atmosphere of uncertainty, which reduce investor confidence and sometimes create situations of panic and insecurity that do not allow for efficient market operations to be undertaken.

Political risks facing international construction companies are increasing with the expanded globalisation of construction activities around the world. Chang et al. (2018) discuss various political risks facing Chinese construction enterprises working overseas. These political risks include macro-factors such as socio-political stability, social safety and the overall performance of the local economy. Cultural factors, often embedded under the category "attitude towards foreigners", are increasingly important source of political risks to Chinese construction firms, characterized by kidnappings and murder of several Chinese construction workers around the world.

Global and regional financial crises do affect the local construction industry. The 1998 Asian financial crisis weakened many economies in the East Asian region. A common observation was the decline of the construction industry in many countries in the region. For example, as noted by Anaman (2003), Sumardi (2003), and Sumardi and Anaman (2004), the 1997/1998 Asian financial crisis led to reduced value of housing and real estate properties and lower supply of construction outputs in Brunei Darussalam resulting in the slowdown of hiring of foreign workers who constituted the bulk of workers in the construction industry.

\subsection{Growth of the Construction Industry in Ghana}

The economy of Ghana is classified into three economic sectors by the Ghana Statistical Service, the official statistics producing agency of Ghana (Ghana Statistical Service, 2018b). These three sectors are: (1) agriculture, (2) industry and (3) services. There are five subsectors of the agricultural sector including the cocoa industry; the latter has been a dominant export-based industry in Ghana over the last 106 years since 1913 (Kotey et al., 1974). There are also 10 subsectors for the services sector.

The construction industry is considered part of the industrial sector. The industrial sector is made up of six subsectors. The other five subsectors in the industrial sector are manufacturing, mining, oil and gas, water production, and electricity production. Altogether, there are 21 recognized subsectors of the economy belonging to the three sectors, of which the construction industry is one, and is the largest of the 21 subsectors (Ghana Statistical Service, 2018b).

The economy of Ghana has undergone gradual transformation, which has resulted in the services sector becoming the most dominant in the economy compared to the other two sectors: agricultural and industrial sectors (refer to Table 1 for the shares of GDP of Ghana attributed to various sectors). For example, over the 2006-2017 period, the services sector was the largest sector of the economy accounting for about $51.3 \%$ of GDP compared to the $25.1 \%$ and $23.6 \%$ shares of GDP for the agricultural and industrial sectors respectively.

Using the nominal value concept for establishing relative rankings of industries employed by the Ghana Statistical Service (2018b), the construction industry accounted on average 10.4\% of the GDP over the 2006 to 2017 period (see Table 1). In 2016 and 2017, the value of the construction industry was about 13.7\% of GDP. In both years, the construction industry was the largest of the 21 subsectors of the economy followed by the non-cocoa crops subsector which had shares of GDP of 12.8\% and 12.4\% for 2016 and 2017 respectively (Ghana Statistical Service, 2018b). 
Table 2 summarises data on the annual growth rates of real GDP, the construction industry, agricultural, industrial and services sectors from 2007 to 2017 using real values of the variables. The average growth of $11.4 \%$ for the construction industry superseded the growth rates of the agricultural, industrial and services sector over this period. In particular, the growth of the construction industry was high over the period, 2007 to 2011, except for 2010. This fast growth of the construction industry was partly due to the infusion of relatively large amounts of grants and loans from development partner countries, which were used for the construction and upgrading of physical infrastructure (Anaman and Bukari, 2019).

However, the growth of the construction industry slowed over the more recent years from 2013 to 2017 linked to the slowdown of economic growth in Ghana. This was partly the result of the relatively lower amounts of grants and gifts coming from Western development partners (Anaman and Bukari, 2019), and the severe electricity energy shortages from 2014 to 2015, which were partly due to the most recent severe 2014-2015 El Nino weather phenomenon. Other possible causes of the slowdown of the construction industry are not immediately clear, necessitating an econometric analysis to ascertain the factors affecting the industry, as is undertaken in this study.

Table 1. Size of Ghana's nominal GDP in millions of Ghana cedis, and the distribution of nominal GDP at basic prices per economic activity and sector from 2006 to 2017 (percent) for the construction industry, agricultural, industrial and services sectors

\begin{tabular}{|c|c|c|c|c|c|}
\hline Year & $\begin{array}{c}\text { Size of Nominal } \\
\text { GDP }\end{array}$ & $\begin{array}{l}\text { Construction } \\
\text { Industry }\end{array}$ & $\begin{array}{l}\text { Agricultural } \\
\text { Sector }\end{array}$ & Industrial Sector & $\begin{array}{l}\text { Services } \\
\text { Sector }\end{array}$ \\
\hline \multicolumn{6}{|l|}{2006} \\
\hline & $18,705.0$ & 5.7 & 30.4 & 20.8 & 48.8 \\
\hline \multicolumn{6}{|l|}{2007} \\
\hline & $23,154.0$ & 7.2 & 29.1 & 20.7 & 50.2 \\
\hline \multicolumn{6}{|l|}{2008} \\
\hline & $30,179.0$ & 8.7 & 31.0 & 20.4 & 48.6 \\
\hline \multicolumn{6}{|l|}{2009} \\
\hline & $36,598.0$ & 8.8 & 31.8 & 19.0 & 49.2 \\
\hline \multicolumn{6}{|l|}{2010} \\
\hline & $46,042.0$ & 8.5 & 29.8 & 19.1 & 51.1 \\
\hline \multicolumn{6}{|l|}{2011} \\
\hline & $59,816.0$ & 8.9 & 25.3 & 25.6 & 49.1 \\
\hline \multicolumn{6}{|l|}{2012} \\
\hline & $75,315.0$ & 11.5 & 22.9 & 28.0 & 49.1 \\
\hline \multicolumn{6}{|l|}{2013} \\
\hline & $93,415.9$ & 12.0 & 22.4 & 27.8 & 49.8 \\
\hline \multicolumn{6}{|l|}{2014} \\
\hline & $113,343.0$ & 12.7 & 21.5 & 26.6 & 51.9 \\
\hline \multicolumn{6}{|l|}{2015} \\
\hline & $136,957.4$ & 13.5 & 20.3 & 25.1 & 54.6 \\
\hline \multicolumn{6}{|l|}{2016} \\
\hline & $167,353.0$ & 13.7 & 18.9 & 24.2 & 56.8 \\
\hline \multicolumn{6}{|l|}{2017} \\
\hline & $205,914.0$ & 13.7 & 18.3 & 25.5 & 56.2 \\
\hline \multicolumn{6}{|l|}{ Average } \\
\hline 2006 to 2017 & - & 10.4 & 25.1 & 23.6 & 51.3 \\
\hline
\end{tabular}


Table 2. Annual growth rates of real GDP, construction industry, agricultural sector, industrial sector and services sector from 2007 to 2017 , based on 2006 constant monetary values (\%)

\begin{tabular}{|c|c|c|c|c|c|}
\hline Year & Real GDP & $\begin{array}{c}\text { Construction } \\
\text { Industry }\end{array}$ & $\begin{array}{l}\text { Agricultural } \\
\text { Sector }\end{array}$ & Industrial Sector & $\begin{array}{c}\text { Services } \\
\text { Sector }\end{array}$ \\
\hline \multicolumn{6}{|l|}{2007} \\
\hline & 4.3 & 23.1 & -1.7 & 6.1 & 7.7 \\
\hline \multicolumn{6}{|l|}{2008} \\
\hline & 9.1 & 39.0 & 7.4 & 15.1 & 8.0 \\
\hline \multicolumn{6}{|l|}{2009} \\
\hline & 4.8 & 9.3 & 7.2 & 4.5 & 5.6 \\
\hline \multicolumn{6}{|l|}{2010} \\
\hline & 7.9 & 2.5 & 5.3 & 6.9 & 9.8 \\
\hline \multicolumn{6}{|l|}{2011} \\
\hline & 14.0 & 17.2 & 0.8 & 41.6 & 9.4 \\
\hline \multicolumn{6}{|l|}{2012} \\
\hline & 9.3 & 16.4 & 2.3 & 11.0 & 12.1 \\
\hline \multicolumn{6}{|l|}{2013} \\
\hline & 7.3 & 8.6 & 5.7 & 6.6 & 10.0 \\
\hline \multicolumn{6}{|l|}{2014} \\
\hline & 4.0 & 0.0 & 4.6 & 0.8 & 5.6 \\
\hline \multicolumn{6}{|l|}{2015} \\
\hline & 3.8 & 2.2 & 2.8 & -0.3 & 6.3 \\
\hline \multicolumn{6}{|l|}{2016} \\
\hline & 3.5 & 2.9 & 3.0 & -1.4 & 5.7 \\
\hline \multicolumn{6}{|l|}{2017} \\
\hline & 8.5 & 4.6 & 8.4 & 16.7 & 4.3 \\
\hline Average & & & & & \\
\hline 2007 to 2017 & 7.0 & 11.4 & 4.2 & 9.8 & 7.7 \\
\hline
\end{tabular}

Note: The figures are sourced from the GDP Statistics based on data from the Ghana Statistical Service published by Ghana Statistical Service in June 2018

\section{Methodology}

\subsection{Model Specification}

Based on the literature review and the underlying problem statement, the methodology used in this study was to build a relatively simple autoregressive model that incorporated various economic shocks, following the approach adopted by Anaman (2018). As proposed by Zellner (1999), the underlying principle for our model development was that of the keeping it sophisticatedly simple (KISS) principle. The "kiss" principle suggests that simple models which provide excellent understanding of an issue are more favoured than complicated and complex models which essentially give the same results. The model used in this study is outlined in Equation 1 in its linear form as follows:

$$
\begin{aligned}
& \text { RCONGDP }_{\mathrm{t}}= \mathrm{A}_{0}+\mathrm{A}_{1} \text { RCONGDP }_{\mathrm{t}-1}+\mathrm{A}_{2} \text { RGDP }_{\mathrm{t}-1}+\mathrm{A}_{3} \text { EXCHANGERATE }_{\mathrm{t}}+\mathrm{A}_{4} \text { TEMPERATURE }_{\mathrm{t}}+ \\
& \mathrm{A}_{5} \text { POLITICALINSTABILITY }_{\mathrm{t}}+\mathrm{A}_{6} \text { EXTREMERAINFALL }_{\mathrm{t}}+\mathrm{A}_{7} \text { ENERGYSHOCK }_{\mathrm{t}}+ \\
& \mathrm{A}_{8} \text { OUTLIER }_{\mathrm{t}}+\mathrm{U}_{\mathrm{t}} \\
& \text { Equation 1 }
\end{aligned}
$$

where RCONGDP R $_{\mathrm{t}}$ is the real output of the construction industry measured as the value added to the real gross domestic product in year $\mathrm{t}$.

$\mathrm{RGDP}_{\mathrm{t}}$ is the real gross domestic product (of the whole economy) in year $\mathrm{t}$.

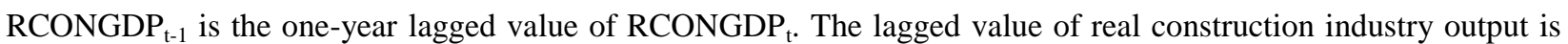
assumed to be related to its current value. 
$\mathrm{RGDP}_{\mathrm{t}-1}$ is the one-year lagged value of $\mathrm{RGDP}_{\mathrm{t}}$. It is postulated that the entire economy as measured by real GDP could drive the growth of the construction industry.

EXCHANGERATE $_{\mathrm{t}}$ refers to the average exchange rate of the Ghana cedi to the United States dollar in year $\mathrm{t}$. An increasing value of the exchange rate denotes the depreciation of the Ghana Cedi. Depreciation of the local currency is assumed to lead to higher costs of imported inputs for construction firms in Ghana and leads to reduced output of the industry.

TEMPERATURE $_{\mathrm{t}}$ is the average temperature for Ghana in year $\mathrm{t}$ measured in degrees Centigrade. Based on the literature, it is assumed that higher average temperatures lead to reduced outputs of the construction industry as activities are rescheduled to reduce the human health impacts of high temperatures on construction workers.

EXTREMERAINFALLYEAR $\mathrm{t}_{\mathrm{t}}$ is a dummy variable taking the value of 1 for years with average country-wide rainfall exceeding 109 centimetres, and zero for years with rainfall amounts less than or equal to 109 centimetres. This value denotes years of occurrence of extremely high rainfall. Extreme rainfall amounts, such as those causing floods, make it difficult or even sometimes impossible for construction activities to be undertaken over a period of time in areas affected by the natural hazards.

ENERGYSHOCK $_{\mathrm{t}}$ refers to the electricity energy production shortfalls from reduced volumes of hydro-based dams in Ghana as a result of severe El Nino weather events and/or droughts in year $t$ with 1 denoting occurrence of the phenomenon and zero otherwise. Based on the available literature (Ofori-Sarpong and Annor, 2012; Masih et al., 2014; Economist Magazine, 2015), the years, 1978, 1982, 1983, 1999, 2006, 2014 and 2015 were assigned a value of 1 reflecting the particularly severe impact of the El Nino weather event on the output of the construction industry in those years. All other years were given a value of zero. It is hypothesized that energy shocks lead to a reduction in the output of the construction industry as construction firms have to incur high costs of using their own energy supplies rather than the relatively cheaper alternative that could be obtained from the national electricity grid.

POLITICALINSTABILITY $\mathrm{t}_{\mathrm{t}}$ refers to the occurrence of a military coup in year $\mathrm{t}$ with 1 denoting occurrence of a coup or attempted coup and zero otherwise. A value of 1 was given for years of military coups or major attempted military coups. Thus, the years, 1972, 1978, 1979, 1981 and 1982 were given a value of 1 . All other years were given a value of zero. As reported in the literature, political instability affects economic activities in the entire country including those in the construction industry through disruptions of programmes and reduced demand from actual and potential customers of the outputs of the industry.

OUTLIER $_{\mathrm{t}}$ was a dummy variable taking the value of 1 for years considered to have unusually very high annual growth rate of the construction industry (36\% or more). Thus, the years, 1975, 1993 and 2008 were given a value of 1. The remaining years from 1968 to 2017 were given a value of zero for this variable. The years, 1975, 1993 and 2008 were noted for substantially increased government expenditures on public works such as the construction and renovation of major stadia for the hosting of the African Cup of Nations soccer tournament.

$\mathbf{U}_{\mathbf{t}}$ is the equation error term initially assumed to be normally distributed with zero mean and constant variance.

The econometric model chosen for the study was based on the natural logarithmic forms of the continuous variables. This model is listed in Equation 2 as follows.

$$
\begin{aligned}
& \text { LRCONGDP }_{\mathrm{t}}= \mathrm{B}_{0}+\mathrm{B}_{1} \text { LRCONGDP }_{\mathrm{t}-1}+\mathrm{B}_{2} \text { LRGDP }_{\mathrm{t}-1}+\mathrm{B}_{3} \text { LEXCHANGERATE }_{\mathrm{t}}+\mathrm{B}_{4} \text { LTEMPERATURE }_{\mathrm{t}}+ \\
& \mathrm{B}_{5} \text { EXTREMERAINFALL }_{\mathrm{t}}+\mathrm{B}_{6} \text { POLITICALINSTABILITY }_{\mathrm{t}}+\mathrm{B}_{7} \text { ENERGYSHOCK }_{\mathrm{t}}+ \\
& \mathrm{B}_{8} \text { OUTLIER }_{\mathrm{t}}+\mathrm{V}_{\mathrm{t}} \\
& \text { Equation } 2
\end{aligned}
$$

where LRCONGDP, LRGDP, LEXCHANGERATE and LTEMPERATURE are the natural logarithmic forms of RCONGDP, RGDP, EXCHANGERATE and TEMPERATURE respectively. $\mathrm{V}_{\mathrm{t}}$ is the equation error term.

A proper use of autoregressive equations for analysis of economic growth implies that the regression analysis is undertaken using stationary variables. The test of stationarity was therefore conducted for the variables, LRCONGDP, LRGDP, LEXCHANGERATE and LTEMPERATURE using unit root tests. These unit root test results are reported in Table 3. The study used two unit root tests, Augmented Dickey-Fuller (ADF) test (Dickey and Fuller, 1981), and the Phillip Perron (PP) test (Phillips and Perron, 1988).

The null hypothesis for both tests was that there was a unit root in the time series. The PP test of stationarity is considered superior to the ADF test due to the PP test having the capability of clearly differentiating non-stationary and stationary time-series with high degree of autocorrelation (Hall and Cummins, 2009). The optimal lag length of the autoregressive analysis used in this study was determined to be one based on the use of both Schwarz-Bayesian Criterion (SBC) and 
Akaike Information Criterion (AIC) as this one-lag length consistently yielded the lowest SBC and AIC values. This finding of one-lag length optimality is similar to the result established by Sun et al. (2013) to explain the variation in the outputs of the construction industry in various European countries.

The unit root test results are reported in Table 3 and they indicate that for both the ADF and PP tests, the two-level variables, LRCONGDP and LRGDP were non-stationary at their levels. However, the first differences of LRCONGDP, LRGDP were stationary (refer to Table 3 for the results for DLRCONGDP and DLRGDP). For LEXCHANGERATE, this variable was non-stationary at the level but stationary at the first difference level based on the PP test at the 10\% level. Using both the ADF and PP unit root test results, LTEMPERATURE was stationary both at the level and at the first difference. However, the significance at the first difference level was much stronger than at the level (refer to Table 3).

Based on the tests of unit roots and stationarity, only the first differences of the natural logarithmic variables were used for the final model specified in Equation 3 as follows:

$$
\begin{aligned}
\text { DLRCONGDP }_{\mathrm{t}}= & \mathrm{C}_{0}+\mathrm{C}_{1} \text { DLRCONGDP }_{\mathrm{t}-1}+\mathrm{C}_{2} \text { DLRGDP }_{\mathrm{t}-1}+\mathrm{C}_{3} \text { DLEXCHANGERATE }_{\mathrm{t}}+ \\
& \mathrm{C}_{4} \text { DLTEMPERATURE }_{\mathrm{t}}+\mathrm{C}_{5} \text { EXTREMERAINFALL }_{\mathrm{t}}+ \\
& \mathrm{C}_{6} \text { POLITICALINSTABILITY }_{\mathrm{t}}+\mathrm{C}_{7} \text { ENERGYSHOCK }_{\mathrm{t}}+\mathrm{C}_{8} \text { OUTLIER }_{\mathrm{t}} \\
& +\mathrm{W}_{\mathrm{t}}
\end{aligned}
$$

where DLRCONGDP, DLRGDP, DLEXCHANGERATE and DLTEMPERATURE are the first differences of the variables, LRCONGDP, LRGDP, LEXCHANGERATE and LTEMPERATURE respectively. $\mathrm{W}_{\mathrm{t}}$ is the equation error term.

As suggested by Gujarati (2003, p. 176), the first difference of an economic variable expressed in natural logarithmic form is equivalent to the growth rate of that variable in its level form. Therefore, the first difference of LRCONGDP (which is noted as DLRCONGDP) represents the annual growth rate of the output of the construction industry. Similarly, DLRGDP, DLEXCHANGERATE and DLTEMPERATURE are the annual growth rate of the real GDP, the annual growth rate of the average depreciation of the Ghana Cedi, and the annual growth rate of the average annual temperature in Ghana, respectively.

The ordinary least squares (OLS) regression estimation method was employed in this study. Initially, with the OLS method, we detected a moderate form of heteroscedasticity. This moderate heteroscedasticity was removed by transforming both the dependent and the independent variables. The OLS method was then used on the transformed variables using the Statistical Package for Social Sciences (SPSS) software. This procedure is sometimes called the generalised least squares method, a variant of the OLS method, and it produces consistent estimators of the parameters (Gujarati, 2003, pp. 419-421).

\subsection{Data and Data Sources}

Data for this study were obtained from various sources. The macroeconomic data related to GDP and the value added to GDP by the construction industry were obtained from the Ghana Statistical Service from 1993 to 2017. The corresponding data concerning nominal time series data on value added to GDP by the construction industry and nominal GDP were obtained from various annual issues of national accounts published by the United Nations Office of National Accounts for Ghana for the period, 1968 to 2014.

Similar data were also obtained from the International Monetary Fund's annual financial statistics publications for Ghana over the period from 1968 to 2017. The three sets of data were reconciled to achieve consistency. The exchange rate of the Ghana cedi to the United States dollar over the 1968 to 2017 were obtained from the Bank of Ghana, the Central Bank of Ghana. Monthly rainfall and temperature data from 1968 to 2015 were obtained from the World Bank Group (2008). The assignment of economic shocks to particular years was based on the review of the literature on economic shocks. 
Table 3. Unit Root tests of the continuous variables at the levels and first differences

\begin{tabular}{lcccc}
\hline Variable & ADF Statistic & P Value & PP Statistic & P Value \\
\hline LRCONGDP & -1.733 & 0.736 & -3.068 & 0.934 \\
\hline LRGDP & -3.313 & 0.064 & -0.396 & 0.994 \\
\hline LEXRATE & -1.805 & 0.702 & -5.199 & 0.807 \\
\hline LTEMPERATURE & -3.470 & $0.043^{* *}$ & -31.203 & $0.007^{* *}$ \\
\hline DLRCONGDP & -3.159 & $0.093^{*}$ & -36.587 & $0.002^{* *}$ \\
\hline DLRGDP & -4.276 & $0.003^{* *}$ & -29.629 & $0.009^{* *}$ \\
\hline DLEXRATE & -2.542 & 0.307 & -21.169 & $0.056^{*}$ \\
\hline DLTEMPERATURE & -7.786 & $0.0001^{* *}$ & -58.404 & $0.00001^{* *}$
\end{tabular}

Notes:

** denotes 5 percent statistical significance

* denotes 10 percent statistical significance

\section{Results}

The results of the autoregressive model analysis of the growth of the construction industry (DLCONRGDP), with its lagged dependent variable, used as one of the independent variables, plus seven other independent variables, are reported in Table 4. As measured by the $\mathrm{R}^{2}$ and the adjusted $\mathrm{R}^{2}$, the power of the model was high with about five -sixth of the variation in the dependent variable explained by the independent variables $\left(R^{2}\right.$ of 0.836$)$. The model was also correctly specified based on the Ramsey Reset Test (Ramsey, 1969). The error term was normally distributed as confirmed by the Kolmogorov-Smirnov (Kolmogorov, 1933; Smirnov, 1948) and the Shapiro-Wilk (Shapiro and Wilk, 1965) tests of normality. Both tests indicated that the null hypothesis of normal error term could not be rejected (refer to Table 4 for the results). The establishment of the normal error term meant that that the sample parameter estimates could be generalized to the parameter values of the unknown population.

There was no significant heteroscedasticity as indicated by the result from the Langrange Multiplier (LM) test proposed by Hall and Cummins (2009) after the correction of an original moderate heteroscedasticity using the generalized least squares method. Finally, the variance inflation factor (VIF) of all the independent variables was very low, all below 2.0 indicating an absence of the problem of multicollinearity. A VIF level of 10.0 is suggested as the critical maximum value below which the hypothesis of the existence of multicollinearity in a model could be rejected (Gujarati, 2003, p. 362). Further, the maximum condition index of the whole model was only 3.081, well below the multicollinearity-detecting threshold level of 30.00. The model also did not have any significant autocorrelation based on the Breusch-Godfrey general test of autocorrelation (Breusch, 1978; Godfrey, 1978).

The results presented in Table 4 indicate that all the variables had their parameters statistically significant at the 5\% level except for the variables, EXTREMERAINFALL. Based on the absolute values of the standardized regression estimates, the most important independent variable affecting the dependent variable (growth of the construction industry) was the POLITICALINSTABILITY; this variable reflected years of military coups in Ghana. The growth of the construction industry was adversely affected by political instability with years of military coups recording an average 21.6 percent decline in growth of the construction industry as compared to the years of no military coups (based on the figure of -0.243 in Table 4). This sharply reduced growth rate could be due to the high risk of delayed payments by military governments to contracts, and also the general uncertainty involved with transitional governments related to military regimes. The second most important independent variable was OUTLIER. This variable reflected the considerable increase in government expenditures on construction activities for the selected years when the government had planned these activities so that they could host major international events in Ghana within one year or two years. Such increased expenditures on construction activities were incurred in 1975, 1993 and 2008 for the hosting of major international events in Ghana.

The other four most important economic shocks affecting economic growth of the construction industry, in order of importance, were (1) the depreciation of the exchange rate, (2) temperature, (3) the energy shock related to electricity energy production shortages, and (4) extreme rainfall shock. All these four factors, except for extreme rainfall, 
adversely affected the growth of the construction industry significantly. Extreme rainfall negatively impacted the growth rate of the construction industry however, this impact was not significant. Because the absolute value of Student $t$ of the parameter estimate of the extreme rainfall variable was greater than 1.0, the variable had to be kept in the model to avoid misspecification bias. Concerning the lagged variables in the model, the results summarized in Table 4 indicate that the parameter estimate of the lagged growth of the construction industry (DLRCONGDP ${ }_{t-1}$ ) was statistically significant implying a negative relationship with the growth of the construction industry. The parameter estimate for DLRGDP $\mathrm{t}_{\mathrm{t}-1}$ was also statistically significant at the 5\% level. Based on standardized parameter estimates, the lagged construction growth variable had a stronger effect than the lagged GDP growth variable (refer to Table 4).

Table 4. Results of autoregressive analysis between annual growth of the construction industry and various economic shocks in Ghana during the 50-year period, 1968-2017

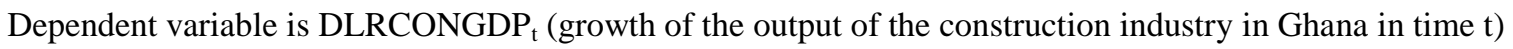

\begin{tabular}{lccccc}
\hline Explanatory variable & $\begin{array}{c}\text { Unstandardized } \\
\text { Parameter } \\
\text { estimate }\end{array}$ & $\begin{array}{c}\text { Standardized } \\
\text { parameter } \\
\text { estimate }\end{array}$ & $\begin{array}{c}\text { Student t } \\
\text { Statistic }\end{array}$ & P value & VIF \\
\hline INTERCEPT & 0.115 & 0.000 & 8.106 & $0.000^{* *}$ & 0.000 \\
\hline DLRCONGDP $_{\mathbf{t}-\mathbf{1}}$ & -0.168 & -0.219 & -2.440 & $0.020^{* *}$ & 1.774 \\
\hline DLRGDP $_{\mathbf{t}-1}$ & 0.353 & 0.167 & 2.111 & $0.042^{* *}$ & 1.376 \\
\hline DLEXCHANGERATE $_{\mathbf{t}}$ & -0.111 & -0.239 & -3.290 & $0.002^{* *}$ & 1.157 \\
\hline DLTEMPERATURE $_{\mathbf{t}}$ & -2.177 & -0.206 & -2.504 & $0.017^{* *}$ & 1.487 \\
\hline EXTREMERAINFALL $_{\mathbf{t}}$ & -0.044 & -0.079 & -1.006 & 0.321 & 1.352 \\
\hline ENERGYSHOCK $_{\mathbf{t}}$ & -0.060 & -0.161 & -2.130 & $0.040^{* *}$ & 1.250 \\
\hline POLITICALINSTABILITY $_{\mathbf{t}}$ & -0.243 & -0.566 & -7.682 & $0.000^{* *}$ & 1.190 \\
\hline OUTLIER $_{\mathbf{t}}$ & 0.326 & 0.538 & 7.128 & $0.000^{* *}$ & 1.251 \\
\hline
\end{tabular}

Notes

$\mathrm{R}^{2} \quad 0.836^{* * *}$

Adjusted $\mathrm{R}^{2} \quad 0.799 * *$

F value $22.920 * *$

Probability level of significance of correct specification of the model using The Ramsey Reset test with null hypothesis of correct model specification 0.175

Probability level of significance of the normality of the error term based on The Shapiro-Wilk test with the null hypothesis of normal error term $\quad 0.148$

Probability level of significance of the normality of the error term based on the Kolmogorov-Smirnov test with the null hypothesis of normal error term $\quad 0.200$

Probability level of significance of the LM test for heteroscedasticity based on the null hypothesis of homoscedasticity (no heteroscedasticity) 0.115

** denotes 5 percent statistical significance

\section{Conclusion and Policy Recommendations}

\subsection{Conclusions}

The study analyses the relationship between the growth of the construction industry and economic shocks in Ghana over the 50-year period from 1968 to 2017 using autoregressive modelling scheme that incorporates increased government expenditures on the construction industry, considered to be a positive economic shock, as an independent variable, and several adverse economic shocks as other separate independent variables. These adverse economic shocks are political instability for military coups, exchange rate depreciation of the local currency, Ghana cedi with respect to the United States dollar, the average yearly temperature, electricity energy production shortfall 
related to the El Nino weather phenomenon, and incidence of extreme rainfall. Our analysis indicated that the most important factor influencing the growth of the construction industry in Ghana over the period of the study was political instability. Beyond political instability, the next most important factor was the purposely-driven sharp increases in government expenditures on construction activities for selected years that allowed the country to host international events. The other significant economic shocks were the exchange rate depreciation, average temperatures, and electricity energy production shortfall, all three factors adversely affected the growth of the construction industry. Extreme rainfall negatively impacted the growth construction industry; however, this impact was not statistically significant. Overall, the results of our study are consistent with those obtained from the reviewed international literature concerning the impacts of economic shocks on the output of the construction industry.

\subsection{Policy Recommendations}

After 27 years of political turbulence in Ghana since the first military coup on 24 February 1966 to the start of the Fourth Republican era on 7 January 1993, political stability has largely been achieved in Ghana over the last 26 years during the Fourth Republican era starting in 1993. Policymakers now need to pay more attention to other factors that affect the growth of the construction industry beyond political instability. Particular attention is needed to work towards maintaining flexible exchange rate stability through more measured and moderate depreciation of the currency that advances the growth of major export-based industries such as the cocoa industry, without damaging other productive sectors, such as the construction industry, which currently rely a lot on imported inputs.

The value of the exchange rate is dependent among others on the macro-economic fundamentals of the country, especially the prices of major exportable goods and services, but also on the degree of speculative activities by local and overseas investors and businessmen, and not the least, sound political-economy fundamentals of the country. It is important for the Bank of Ghana to be much more proactive in the preparation of strategic and tactical defence of the currency through improved risk management techniques and systems. The recent explosive depreciation of the Ghana cedi that occurred during the January to March 2019 period apparently caught many officials and policymakers by surprise, given the extent of its turbulence, and noting the consistent and regular pronouncements by several top government officials throughout 2018 that the economy had sound macro-economic fundamentals.

Since the start of the flexible managed floating regime of the currency in Ghana, about three decades ago, the Ghana cedi has exhibited fairly-predictable periods of explosive depreciation, in tandem with moderate depreciation over much of the calendar year. The Ghana cedi-United States dollar exchange rate largely exhibits a unit root time-series characteristic, hardly returning to a mean value, with economic shocks and fluctuations registering a permanent upward effect on the exchange rate. However, more proactiveness by the Bank of Ghana could reduce the degree and intensity of the recurring explosive depreciation of the currency. It is the recurring explosive depreciation and associated turbulence of the exchange rate which particularly hurt the construction industry and other economic sectors relying on imported inputs.

Further, given the clear impact of electricity energy production shortfall on the performance of the construction industry, and also on other industries in Ghana, policy makers need to work earnestly towards the expansion of the country's electricity generation capacity. Attention should be on those that come from non-hydro sources to meet the needs of industries and consumers, given the uncertainty associated with the production from hydro-based dams as a result of the climate change and frequent occurrences of the El Nino weather phenomenon, which generates large scale and severe droughts at least once every decade in Ghana. As pointed out by Anaman (2018), in Ghana, a lot more efforts are made by policymakers in the immediate aftermath of severe El Nino events, which reduce the supply of electricity, due to reduced capacity of the three hydro-based dams in the country. After that, the complacency "disease" sets in and affects policymakers as little is added to the national electricity generation capacity, despite official government public pronouncements of active work in that area, until another severe El Nino event hits the country. The complacency of policymakers would need to stop in order to ensure sustainable electricity generation that helps the growth of the construction industry and other sectors of the economy.

Finally, the impact of extreme temperatures and rainfall on the growth of the construction industry need to be incorporated into the decision-making processes of construction firms on a priority basis given the effects of climatic change in Ghana. In this regard, the production of enhanced locality-specific weather and climate information by the Ghana Meteorological Agency for business firms including those in the construction industry needs to be given higher priority with increased funding by the government to support such activities. 


\section{References}

Anaman, K.A. (2003). Can the Construction Industry Pull the Rest of The Economy out of a Recession? Evaluation of the Causality Links between the Construction Industry and the Macroeconomy in Brunei Darussalam. In Anaman, K.A. and Duraman, I. (Eds.), Applied Economic Analysis in Brunei Darussalam: Evaluation of Economic Growth and Trade, Microeconomic Efficiency and Analysis of Socio-economic Problems. Bandar Seri Begawan, Brunei Darussalam: Universiti Brunei Darussalam.

Anaman, K.A. (2006). Determinants of Economic Growth in Ghana. Accra: The Institute of Economic Affairs.

Anaman, K.A. (2018). Economic Shocks and Growth in the Post-Independence Period, 1957 to 2017. Accra: Ghana: Institute for Fiscal Studies.

Anaman, K. A., \& Osei-Amponsah, C. (2007). Analysis of the Causality Links Between the Growth of the Construction Industry and the Growth of the Macro-economy in Ghana. Construction Management and Economics, 25(9), 951-961. https://doi.org/10.1080/01446190701411208

Anaman, K.A., Quaye, R., \& Amankwah, E. (2017). Evaluation of the Public Weather Services by Users in the Formal Services Sector in Accra, Ghana. Modern Economy, 8, 921-945. https://doi.org/10.4236/me.2017.87065

Anaman, K.A., \& Bukari. (2019). Political Economy Analysis of the Macroeconomic Impact of National Elections in Ghana During the Fourth Republican Era, 1992-2016. Applied Economics and Finance, 6(3), 28-44. https://doi.org/10.11114/aef.v6i3.4202

Ballesteros-Perez, P., Smith, S.T., Lloyd-Papworth, J.G., \& Cooke, P. (2018). Incorporating the Effect of Weather in Construction Scheduling and Management with Sine Wave Curves: Application in the United Kingdom. Construction Management and Economics, 36(12), 666-682. https://doi.org/10.1080/01446193.2018.1478109

Bank of Ghana. Statistics and Publications. Retrieved 14 April 2019, from https://www.bog.gov.gh/whars-new

Breusch, T.S. (1978). Testing for Autocorrelation in Dynamic Linear Models. Australian Economic Papers, 17, $334-335$. https://doi.org/10.1111/j.1467-8454.1978.tb00635.x

Buah, F.K. (1998). A History of Ghana. London: MacMillan.

Chang, T., Deng, X., Hwang, B., \& Zhao, X. (2018). Political Risk Paths in International Construction Projects: Case Study of Chinese Construction Enterprises. Advances in Civil Engineering, 11. https://doi.org/10.1155/2018/6939828

Davidson, B. (1972). History of Africa. London: Spring Books.

Dell, M., Jones, B. F., \& Olken, B.A. (2014). What We Do Learn from the Weather? The New Climate Economy Literature. Journal of Economic Literature, 52(3), 740-798. https://doi.org/10.1257/jel.52.3.740

Dickey, D., \& Fuller, W.A. (1981). Likelihood Ratio Statistics for Autoregressive Time Series with a Unit Root. Econometrica, 49, 1057-1072. https://doi.org/10.2307/1912517

Dzawu, M.M. (2019). Worst-Performing Stocks Found in Ghana as Foreigners Exit. Bloomberg News, March 29 $\begin{array}{lllll}\text { Edition. } & \text { Retrieved } & 5 & \text { April } & \text { 2019, from }\end{array}$ https://www.bloomberg.com/news/articles/2019-03-29/worst-performing-stocks-are-found-in-ghana-as-foreigne rs-exit

Economist Magazine. (2015). El Nino Threatens Africa. Economist Magazine, October 14.

Ellis, A. B. (1894). A History of the Gold Coast of West Africa. London: Chapman and Hall.

El-Rayes, K., \& Moselhi, O. (2001). Impact of Rainfall on the Productivity of Highway Construction. Journal of Construction Engineering and Management, $127(2), \quad$ https://doi.org/10.1061/(ASCE)0733-9364(2001)127:2(125)

Erol, I., \& Unal, U. (2015). Role of Construction Sector in Economic Growth: Evidence from Turkey. MPRA Paper No. 68263. Retrieved 6 May 2019, from https://mpra.ub.uni-muenchen.de/68263/

Fernandez, A., Schmitt-Grohe, S., \& Uribe, M. (2017). World Shocks, World Prices, and Business Cycles: An Empirical Investigation. Journal of International Economics, 108, S2-S14. https://doi.org/10.1016/j.jinteco.2017.01.001

Ghana Statistical Service (GSS). (2013). 2010 National Population and Housing Census: National Analytic Report. Accra: GSS. 
Ghana Statistical Service (GSS). (2018a). 2017 Annual GDP by Expenditures June 2018 Edition. Accra, Ghana: GSS.

Ghana Statistical Service (GSS). (2018b). Provisional 2017 Annual Gross Domestic April 2018 Edition. Accra, Ghana: GSS.

Godfrey, L.G. (1978). Testing against General Autoregressive and Moving Average Error Models when the Regressors Include Lagged Dependent Variables. Econometrica, 46, 1293-1302. https://doi.org/10.2307/1913829

Gujarati, B.N. (2003). Basic Econometric Methods Fourth Edition. New York: Prentice Hall.

Hall, B. H., \& Cummins, C. (2009). Time Series Processor Version 5 Reference Manual. Palo Alto, California: TSP International.

International Monetary Fund (IMF). International Financial Statistics, Various Annual Issues from 1956 to 2006. Washington, D.C.: IMF.

Karley, N.K. (2011). Remittances to Ghana: Benefits to the Housing Sector and Impact of Financial Crisis. In Laryea, S., Leiringer, R., \& Hughes, W. (Eds), Proceedings of the West Africa Built Environment Research (WABER) Conference, 19-21 July 2011, Accra, pp. 827-840.

Kolmogorov, A. (1933). Sulla Determinazione Empirica di Una Legge di Distribuzione. G. Ist Ita. Attuari, 4, 83-91.

Kotey, R.A., Okali, C., \& Rourke, B.E. (Eds.) (1974). Economics of Cocoa Production and Marketing. Legon, Accra: University of Ghana.

Laryea, S. A. (2010). Challenges and Opportunities Facing Contractors in Ghana. In Proceedings of the West Africa Built Environment Research (WABER) Conference, 27-28 July 2010, Accra, pp. 215-226.

Lynch, H.R. (1968). Introduction. In J.M. Sarbah (Ed.), Fante National Constitution and Law Reports. London: Frank Cass and Company.

Masih, I., Maskey, S. Mussa, F.E.F., \& Trambauer, P. (2014). A Review of Droughts on the African Continent: A Geospatial and Long-term Perspective. Hydrology and Earth System Sciences, 18, 3635-3649. https://doi.org/10.5194/hess-18-3635-2014

McConnell, C.R., Brue, S.L., \& Flynn, S.M. (2016). Economics: Principles, Problems and Policies (19th ed.). New York: McGraw-Hill.

Nti, K. (2002). An Overview of the Ding Dong Relationship between the Colonial Government and the People of Cape Coast. Nordic Journal of African Studies, 11(1), 1-37.

Ofori-Sarpong, E., \& Annor, E. (2012). Rainfall in Accra 1901 to 1990. Weather, 56(2), 55-62. https://doi.org/10.1002/j.1477-8696.2001.tb06535.x

Okoye, P.U., Mbakwe, C.C., \& Ndifreke. (2018). Modeling the Construction Sector and Oil Prices Toward the Growth of the Nigerian Economy: An Econometric Approach. Economies, 6(16), 1-19. https://doi.org/10.3390/economies6010016

Oladinrin, T.O., Ogunsemi, D.R., \& Aje, I.O. (2012). The Role of Construction Sector in Economic Growth: Empirical Evidence from Nigeria. Futy Journal of the Environment, 7(1), 50-60. https://doi.org/10.4314/fje.v7i1.4

Phillips, P., \& Perron, P. (1988). Testing for a Unit Root in Time-series Regression. Biometrica, 75, 335-346. https://doi.org/10.1093/biomet/75.2.335

Ramsey, J.S. (1969). Tests for Specification Errors in Classical Linear Least Squares Regression. Journal of the Royal Statistical Society, Series B, 350-371. https://doi.org/10.1111/j.2517-6161.1969.tb00796.x

Shapiro, S.S., \& Wilk, M.B. (1965). An Analysis of Variance Test for Normality (complete samples). Biometrika, 52(3-4), 591-611. https://doi.org/10.1093/biomet/52.3-4.591

Smirnov, N. (1948). Table for Estimating the Goodness of Fit of Empirical Distributions. Annals of Mathematical Statistics, 19(2), 279-281. https://doi.org/10.1214/aoms/1177730256

Sultan, B., \& Alaghbari, W. (2018). Political Instability and the Informal Construction Sector in Yemen. International Journal of Civil Engineering and Technology, 9(11), 1228-1235. 
Sumardi, R.H. (2003). A Survey-based Analysis of Factors Influencing the Efficiency of the Construction Industry in Brunei Darussalam. In Anaman, K.A. and Duraman, I. (Eds.), Applied Economic Analysis in Brunei Darussalam: Evaluation of Economic Growth and Trade, Microeconomic Efficiency and Analysis of Socio-economic Problems. Bandar Seri Begawan, Brunei Darussalam: Universiti Brunei Darussalam.

Sumardi, R.H., \& Anaman, K.A. (2004). Aggregate Efficiency Analysis of Resource Use and Demand for Labour by the Construction Industry in Brunei Darussalam. Construction Management and Economics, 22, 755-764.

Sun, Y., Mitra, P., \& Simonel, A. (2013). The Driving Force Behind the Boom and Bust in Construction in Europe. Washington, D.C.: International Monetary Fund. https://doi.org/10.5089/9781484392485.001

Wang, T.H. (1987). Construction and Development. Kuala Lumpur: Pelanduk Publications.

Ward, W.E.F. (1948). A History of the Gold Coast. London: George Allen and Unwin.

World Bank Group. (2018). Climate Change Knowledge Portal for Development Practitioners and Policymakers. Washington, D.C.: World Bank, 1 May 2019.

Zellner, A. (1999). Keep it Sophisticatedly Simple. Berkeley: Department of Agricultural and Resource Economics and Policy, University of California.

\section{Notes}

Note 1 . The nine relatively big and dominant social/ethnic groups in Ghana, based on population strength from the five national population censuses organized by the Ghana Statistical Service, and using the most reliable 2000 census figures, are (1) Asantes (14.8\%), (2) Ewes (12.7\%), (3) Fantes (9.9\%), (4) Bonos (4.6\%), (5) Dangmes (4.3\%), (6) Dagombas (4.3\%), (7) Gas (3.4\%), (8) Akyems (3.4\%), and (9) Akuapems (2.9\%) These nine dominant social/ethnic groups make up about $60 \%$ of the population of citizens; the remaining 80 relatively small social/ethnic groups constitute about $40 \%$ of the population (Ghana Statistical Service, 2013).

Note 2. The original 17 traditional African states in the Gold Coast area which signed the 6 March 1844 security pact with the Government of the United Kingdom of Great Britain were Abora, Agona (Agona Nsaba), Ajumako, Anomabu, Asikuma (Breman Asikuma), Assin Attandasu, Assin Apemanim, Cape Coast, Denkyira, Dixcove, Dominase, Ekumfi, Gomoa, James Town (Accra), Twifo, Wassa Amenfi and Wassa Fiase (Ward, 1948; Davidson, 1972). Over 170 additional traditional states were added to this original Gold Coast entity by the British Government over the 100-year period from 1856 to 1956 through military conquest, negotiations, and the successful holding of the United Nations referendum on Trans-Volta Togoland (or British Togoland) held on 9 May 1956 (Buah, 1998).

Note 3. The first of the four major independence movements was the Movement led by King Aggrey of Cape Coast which started in March 1865 and lasted for over 30 years culminating in the formation of the Aborigines Rights Protection Society (ARPS) on 17 May 1897 at Cape Coast.

The second major movement, ARPS, was formed by Mr. John Mensah Sarbah, a distinguished lawyer from Cape Coast, and a group of intellectuals and chiefs. ARPS lasted for about 40 years from May 1897 to the mid-1930s.

The third major movement was the United Gold Coast Convention (UGCC). UGCC was founded by Mr. George Grant, a timber merchant and financier of the group, and some intellectuals in August 1947, with the organization registered in Sekondi in 1947 by Mr. (Lawyer) R.S. Blay. The UGCC lasted for only three years and was unable to contest the first national election in February 1951 due to its breakup and dissolution in 1950.

The fourth major movement, Convention People's Party (CPP), was founded in June 1949 by Dr. Kwame Nkrumah. The CPP led the Gold Coast to political independence on 6 March 1957 winning all three national elections organized by the British Colonial Government in 1951, 1954 and 1956 (Ellis, 1894; Ward, 1948; Davidson, 1972; Buah, 1998). 